\title{
Regional differences in land use affect population performance of the threatened insectivorous plant Drosophyllum lusitanicum (Droseraceae)
}

\author{
B. GARRIDO ${ }^{*}$, A. HAMPE${ }^{1}$, T. MARAÑ $\mathrm{N}^{2}$ and J. ARROYO ${ }^{1}{ }^{1}$ Dept. de Biología \\ Vegetal y Ecología, Universidad de Sevilla, Apartado 1095, E-41080 Sevilla, Spain and ${ }^{2}$ Irna, Csic, \\ Po Box 1052, E-41080 Sevilla, Spain
}

\begin{abstract}
We analyse populations of the insectivorous plant Drosophyllum lusitanicum (L.) Link (Droseraceae) and their habitats throughout the species' distribution range (Portugal, Spain and Morocco), and examine their relations. We have surveyed 32 populations and we analyse their demographic structures, accompanying plant communities (by TWINSPAN analyses), and relationships between population features and several edaphic and nonedaphic environmental variables (by multiple regression analyses). Plant communities, their floristic richness and degree of endemism change across the geographical range of Drosophyllum. Populations vary strongly in size, density and age structure. Their recruitment seems largely determined by competition with the surrounding vegetation, while only weak relationships were detected between population performance and other environmental factors. The demographic structure of populations exhibits a marked geographical differentiation, with populations becoming older and sparser towards
\end{abstract}

the north-western part of the range. The largest and presumably most stable populations are mostly found in southern Spanish heathlands, which are nowadays scarcely affected by man. Moroccan populations suffer from browsing by cattle and experience an accelerated generation turnover, while most Portuguese populations occur in afforested areas and experience strongly reduced recruitment. The historical distribution range of Drosophyllum within its peculiar habitat has probably been relatively stable, but recent regional differences in human land use have resulted in present-day differences in population performance, as well as in types and degrees of threat across the three countries involved. Conservation strategies should take into account this range-wide variation and combine approaches on different spatial scales.

Key words. Carnivorous plant, conservation, demographic structure, ecogeography, geographical range, Mediterranean heathland, range-wide survey, regeneration.

\section{INTRODUCTION}

Geographic ranges are manifestations of complex interactions between the intrinsic characteristics of organisms (particularly their environmental tolerance, resource requirements, life history and dispersal capacity) and the characteristics of their environment. The populations that make up a species' geographical range underlie a template

\footnotetext{
* Corresponding author. E-mail: bego@us.es
}

of environmental conditions, which is singular at every site. The diverse consequences of this geographical variability have stimulated research in many aspects of biogeography (Brown et al., 1996), as well as related disciplines like ecology (e.g. Joshi et al., 2001; Sagarin \& Gaines, 2002), evolutionary biology (Thompson, 1994) or conservation biology (e.g. Gärdenfors, 2001; Scott et al., 2001; Rodrigues \& Gaston, 2002).

However, while large-scale geographical patterns of morphological and genetic variation 
have commonly been studied and range-wide patterns of abundance comprise an important issue in biogeography and macroecology (Brown et al., 1996), few surveys have explored the geographical variability of populations and their respective environments beyond local or regional levels. Consequently, while it is a widely accepted paradigm that the ability of species to cope with their environment determines their patterns of distribution, little attention has been paid to the question of how this ability may change across species' ranges. Moreover, current distribution ranges of species are constrained by historical processes, which have produced patterns that cannot be explained by current local environmental conditions (Brown et al., 1996; Avise, 2000; see also Peterken \& Game, 1984). Population surveys across the present-day distribution range may allow making inferences about the relative importance of historical vs. contemporaneous factors as determinants of a species' distribution. Additionally, different zones within a species range are connected by means of colonization and extinction processes, which may also show temporal variability. Even at the scale of single population, demographical parameters may show high temporal variability.

Here we focus on spatial variability of populations and habitats of the insectivorous plant Drosophyllum lusitanicum (L.) Link throughout its range on the Iberian Peninsula and in northern Morocco (Fig. 1). The region covered by this study has been investigated by numerous biogeographers because of its high biodiversity and elevated degree of endemism (Lobo et al., 2001). This high biotic richness is usually explained by the high environmental heterogeneity and the peculiar historical biogeography of the region, particularly its role as ancestral area of speciation and climate refugium during the Quaternary (see Palmer \& Cambefort, 2000; Lobo et al., 2001; García-Barrios et al., 2002; for brief reviews).

Drosophyllum lusitanicum (Drosophyllum, hereafter) has attracted the interest of naturalists for a long time (e.g. Darwin, 1875), and many authors have remarked its peculiar biology (e.g. it is the only carnivorous plant of the northern hemisphere adapted to grow in dry habitats; Givnish et al., 1984; Juniper et al., 1989). Recent studies (Williams et al., 1994; Meimberg et al.,

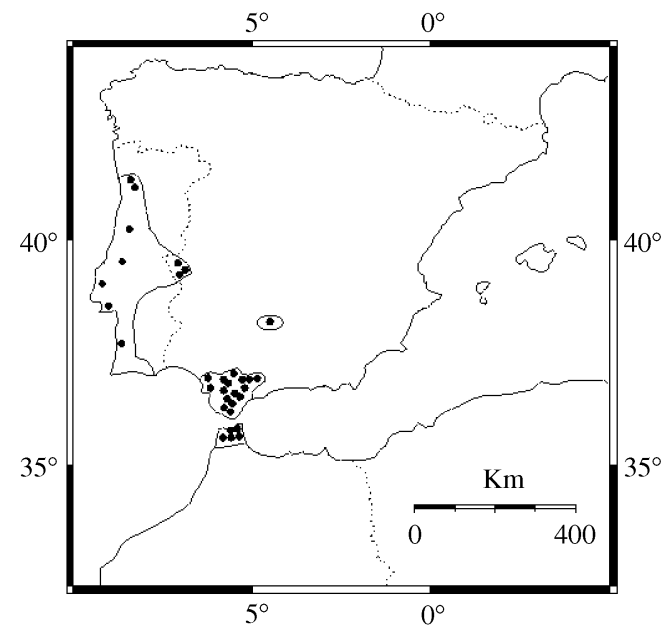

Fig. I Geographical range of Drosophyllum lusitanicum and location of sample sites. See Table 1 for further details on the localities.

2000) have emphasized the phylogenetic distinctness of Drosophyllum and even suggest creating a new monospecific family. In this case it would represent one of the few endemic plant families of the Mediterranean Basin (Takhtajan, 1986; Heywood, 1993). However, despite the ecological and phylogenetic singularity of Drosophyllum, the plant's reproductive biology has only recently been studied (Ortega et al., 1995, 1998), and its habitat requirements are little known (but see Müller \& Deil, 2001; Correia \& Freitas, 2002). It is usually found in scrublands with sparse herbaceous cover on acid, poor soils. The species is considered to be in decline; it is included in the Andalusian Red List of Threatened Plants (BOJA, 1994), is considered quite rare in Morocco (Fennane \& Ibn Tattou, 1998) and threatened with a highly fragmented range in Portugal (Caldas et al., 1996).

The aims of the present paper are:

1. To document the character of Drosophyllum populations throughout the species' geographical range;

2. To describe plant communities at their growing sites;

3. To analyse the relationships between environmental factors and population performance, with special emphasis on regional-scale spatial variability; and 
4. To evaluate the conservation status of Drosophyllum stands throughout its range.

\section{MATERIALS AND METHODS}

\section{Field sampling}

A total of 32 Drosophyllum populations were examined between March and July 1997 and in July 1998 (Fig. 1 and Table 1). The spatial distribution and density of the sampling sites reflects approximately the abundance of Drosophyllum populations across its geographical range. Populations were localized on the basis of available information provided by published localities, herbarium specimens, a recent survey in Portugal (Caldas et al., 1996), unpublished information, and own preliminary explorations. At each sampling site we estimated the total area occupied by the population, and placed a $10 \times 20 \mathrm{~m}$ plot inside that area, represented the main habitat. We counted all plants inside the plot and assigned them to different age classes (Fig. 2): E-1, subadults without floral scapes; E-2, adults reproducing for the first time, only with unramified shoots with one floral scape; and E-3, older adults with ramified shoots and several floral scapes. Recently germinated seedlings were counted separately. When the total population area was smaller than $200 \mathrm{~m}^{2}$ (plot size), we counted all plants and seedlings in that area (this occurred in 6 out of 32 sites, see Table 1 ).

At each sampling site, we recorded the altitude about sea level (using altimeter and topographical maps), the mean slope and its orientation (in degrees of deviation from the south). We collected subsamples of superficial soil (the uppermost $15 \mathrm{~cm}$ ) at five randomly chosen points within each plot, to make one mixed soil sample, and analysed its particle size distribution (using a Boyoucos hydrometer), $\mathrm{pH}$ (electrometrically), $\mathrm{CaCO}_{3}$ (manometrically), organic $\mathrm{C}$ (by a modified Walkley and Black method), total N (by Kjeldahl) and $\mathrm{P}$ (by visible spectrophotometry after sodium bicarbonate extraction). Details on the used analytical methods can be found in Allen (1989).

We measured the cover of woody plant species (including Drosophyllum) and bare soil along a

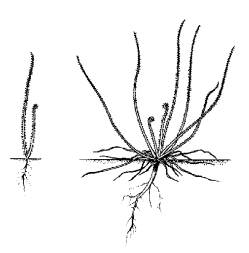

A

B

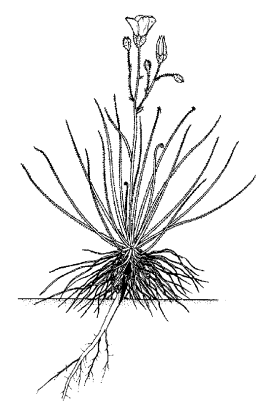

C

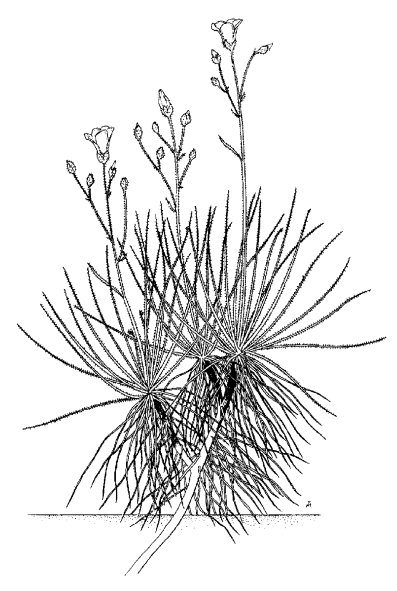

D

Fig. 2 Drosphyllum plant size classes used in demographic surveys. A, seedling (double size); B, subadult plant without floral scapes (class E-1); C, adult reproducing for the first time, with unramified shoot and only one floral scape (E-2); D, older adult with ramified shoots and several floral scapes (E-3). Plants reproduce from the second year onwards and may reach an age of about 10 years (cf. Juniper et al., 1989). They develop floral scapes that persist after fruiting and usually form the basis of two new shoots that start to flower in the following year. Therefore, individuals with many branched stems and clusters of leaves are older than those with a single stem. However, shoots are frequently lost (e.g. due to drought damages), which precludes an exact determination of the plant age by simple branch counting. 
Table I Locations and features of the studied Drosophyllum populations. Plant density (excluding seedlings), age classes and seedling number were recorded in a $200-\mathrm{m}^{2}$ sampling area

\begin{tabular}{|c|c|c|c|c|c|c|c|c|c|c|c|}
\hline $\mathrm{n}^{\circ}$ & Country & Coordinates & $\begin{array}{l}\text { Altitude } \\
\text { (m a.s.l.) }\end{array}$ & Habitat & $\begin{array}{l}\text { TWINSPAN } \\
\text { group }\end{array}$ & $\begin{array}{l}\text { Area } \\
\left(\mathrm{m}^{2}\right)\end{array}$ & $\begin{array}{l}\text { Density } \\
\text { (ind. } / 200 \mathrm{~m}^{2} \text { ) }\end{array}$ & $\begin{array}{l}\text { E-3 } \\
(\%)\end{array}$ & $\begin{array}{l}\text { E-2 } \\
(\%)\end{array}$ & $\begin{array}{l}\text { E-1 } \\
(\%)\end{array}$ & $\begin{array}{l}\text { seedling } \\
\text { number }\end{array}$ \\
\hline 1 & Morocco & $35^{\circ} 46^{\prime}-\mathrm{N} 5^{\circ} 39^{\prime}-\mathrm{W}$ & 110 & Roadside & I & 50 & 17 & 52.9 & 0 & 47.1 & 0 \\
\hline 2 & Morocco & $35^{\circ} 48^{\prime}-\mathrm{N} 5^{\circ} 34^{\prime}-\mathrm{W}$ & 150 & Open scrub & I & 10000 & 67 & 11.9 & 40.3 & 47.8 & 67 \\
\hline 3 & Morocco & $35^{\circ} 52^{\prime}-\mathrm{N} 5^{\circ} 21^{\prime}-\mathrm{W}$ & 80 & Open scrub & I & 2100 & 243 & 16.5 & 14.4 & 69.1 & 25 \\
\hline 4 & Morocco & $35^{\circ} 46^{\prime}-\mathrm{N} 5^{\circ} 24^{\prime}-\mathrm{W}$ & 150 & Open scrub & I & 325 & 168 & 8.3 & 11.9 & 79.8 & 20 \\
\hline 5 & Morocco & $35^{\circ} 38^{\prime}-\mathrm{N} 5^{\circ} 51^{\prime}-\mathrm{W}$ & 100 & $\begin{array}{l}\text { Eucalyptus } \\
\text { plantation }\end{array}$ & I & 5000 & 650 & 0.2 & 20.0 & 79.8 & 50 \\
\hline 6 & Spain & $36^{\circ} 20^{\prime}-\mathrm{N} 5^{\circ} 09^{\prime}-\mathrm{W}$ & 10 & Open coastal scrub & II & 400 & 106 & 6.6 & 41.5 & 51.9 & 11 \\
\hline 7 & Spain & $36^{\circ} 10^{\prime}-\mathrm{N} 5^{\circ} 36^{\prime}-\mathrm{W}$ & 450 & Heathland & II & 3750 & 15 & 40.0 & 20.0 & 40.0 & 0 \\
\hline 8 & Spain & $36^{\circ} 10^{\prime}-\mathrm{N} 5^{\circ} 36^{\prime}-\mathrm{W}$ & 450 & Pinus plantation & II & 10000 & 17 & 23.5 & 41.2 & 35.3 & 8 \\
\hline 9 & Spain & $36^{\circ} 34^{\prime}-\mathrm{N} 5^{\circ} 07^{\prime}-\mathrm{W}$ & 20 & Pinus plantation & $\mathrm{I}$ & 450 & 203 & 17.2 & 61.1 & 21.7 & 9 \\
\hline 10 & Spain & $36^{\circ} 17^{\prime}-\mathrm{N} 5^{\circ} 33^{\prime}-\mathrm{W}$ & 530 & Heathland & II & $>15000$ & 131 & 13.0 & 52.7 & 34.4 & 0 \\
\hline 11 & Spain & $36^{\circ} 16^{\prime}-\mathrm{N} 5^{\circ} 33^{\prime}-\mathrm{W}$ & 520 & Heathland with Pinus & II & $>15000$ & 348 & 0.6 & 54.9 & 44.5 & 0 \\
\hline 12 & Spain & $36^{\circ} 17^{\prime}-\mathrm{N} 5^{\circ} 29^{\prime}-\mathrm{W}$ & 240 & Heathland & II & 2500 & 301 & 0.7 & 2.0 & 97.3 & 43 \\
\hline 13 & Spain & $36^{\circ} 17^{\prime}-\mathrm{N} 5^{\circ} 29^{\prime}-\mathrm{W}$ & 240 & Quarry & I & 450 & 165 & 19.4 & 15.8 & 64.8 & 73 \\
\hline 14 & Spain & $36^{\circ} 25^{\prime}-\mathrm{N} 5^{\circ} 30^{\prime}-\mathrm{W}$ & 580 & Slashed heathland & II & 200 & 44 & 22.7 & 15.9 & 61.4 & 0 \\
\hline 15 & Spain & $36^{\circ} 35^{\prime}-\mathrm{N} 5^{\circ} 12^{\prime}-\mathrm{W}$ & 600 & $\begin{array}{l}\text { Roadside in } \\
\text { Eucalyptus plantation }\end{array}$ & II & 4500 & 675 & 0.6 & 16.9 & 82.0 & 40 \\
\hline 16 & Spain & $36^{\circ} 36^{\prime}-\mathrm{N} 5^{\circ} 22^{\prime}-\mathrm{W}$ & 660 & Heathland & II & 400 & 243 & 1.2 & 9.9 & 88.9 & 26 \\
\hline 17 & Spain & $36^{\circ} 36^{\prime}-\mathrm{N} 5^{\circ} 23^{\prime}-\mathrm{W}$ & 700 & Heathland & II & 400 & 139 & 50.4 & 24.5 & 25.2 & 4 \\
\hline 18 & Spain & $36^{\circ} 31^{\prime}-\mathrm{N} 5^{\circ} 38^{\prime}-\mathrm{W}$ & 775 & Heathland & II & $>15000$ & 412 & 14.8 & 36.4 & 48.8 & 1 \\
\hline 19 & Spain & $36^{\circ} 31^{\prime}-\mathrm{N} 5^{\circ} 37^{\prime}-\mathrm{W}$ & 775 & Heathland & II & $>15000$ & 723 & 18.5 & 20.1 & 61.4 & 0 \\
\hline 20 & Spain & $36^{\circ} 29^{\prime}-\mathrm{N} 5^{\circ} 36^{\prime}-\mathrm{W}$ & 700 & Heathland & II & $>15000$ & 128 & 43.0 & 30.5 & 26.6 & 0 \\
\hline 21 & Spain & $38^{\circ} 28^{\prime}-\mathrm{N} 4^{\circ} 24^{\prime}-\mathrm{W}$ & 1280 & Heathland & IV & 200 & 286 & 62.6 & 3.8 & 33.6 & 0 \\
\hline 22 & Portugal & $40^{\circ} 22^{\prime}-\mathrm{N} 8^{\circ} 18^{\prime}-\mathrm{W}$ & 150 & Eucalyptus plantation & III & 2500 & 25 & 100.0 & 0.0 & 0.0 & 0 \\
\hline 23 & Portugal & $38^{\circ} 33^{\prime}-\mathrm{N} 9^{\circ} 06^{\prime}-\mathrm{W}$ & 150 & Pinus plantation & I & 500 & 14 & 28.6 & 28.6 & 42.9 & 0 \\
\hline 24 & Portugal & $39^{\circ} 13^{\prime}-\mathrm{N} 8^{\circ} 58^{\prime}-\mathrm{W}$ & 150 & Pinus plantation & III & 1250 & 36 & 66.7 & 22.2 & 11.1 & 0 \\
\hline 25 & Portugal & $39^{\circ} 26^{\prime}-\mathrm{N} 8^{\circ} 50^{\prime}-\mathrm{W}$ & 150 & Eucalyptus plantation & III & 40 & 23 & 47.8 & 21.7 & 30.4 & 0 \\
\hline 26 & Portugal & $41^{\circ} 11^{\prime}-\mathrm{N} 8^{\circ} 31^{\prime}-\mathrm{W}$ & 250 & Heathland & III & 50 & 21 & 81.0 & 19.0 & 0.0 & 0 \\
\hline 27 & Portugal & $41^{\circ} 14^{\prime}-\mathrm{N} 8^{\circ} 30^{\prime}-\mathrm{W}$ & 280 & Heathland & III & 10000 & 10 & 80.0 & 20.0 & 0.0 & 0 \\
\hline 28 & Portugal & $37^{\circ} 30^{\prime}-\mathrm{N} 8^{\circ} 42^{\prime}-\mathrm{W}$ & 200 & Roadside & II & 15 & 31 & 22.6 & 77.4 & 0.0 & 0 \\
\hline 29 & Spain & $39^{\circ} 16^{\prime}-\mathrm{N} 6^{\circ} 59^{\prime}-\mathrm{W}$ & 500 & Pinus plantation & IV & 240 & 526 & 63.9 & 31.2 & 4.9 & 0 \\
\hline 30 & Spain & $39^{\circ} 16^{\prime}-\mathrm{N} 6^{\circ} 59^{\prime}-\mathrm{W}$ & 525 & $\begin{array}{l}\text { Scrub beneath } \\
\text { Quercus suber stand }\end{array}$ & $\begin{array}{l}\text { IV } \\
0\end{array}$ & 500 & 826 & 50.8 & 28.8 & 20.3 & 0 \\
\hline 31 & Spain & $39^{\circ} 24^{\prime}-\mathrm{N} 7^{\circ} 12^{\prime}-\mathrm{W}$ & 700 & $\begin{array}{l}\text { Roadside in } \\
\text { Eucalyptus plantation }\end{array}$ & $\begin{array}{l}\text { IV } \\
0\end{array}$ & 1875 & 207 & 41.1 & 18.8 & 40.1 & 0 \\
\hline 32 & Spain & $36^{\circ} 36^{\prime}-\mathrm{N} 5^{\circ} 30^{\prime}-\mathrm{W}$ & 600 & Heathland & II & 200 & 121 & 0.8 & 9.9 & 89.3 & 3 \\
\hline
\end{tabular}


randomly located $25-\mathrm{m}$ line transect. The precision of recorded transect intersections was adjusted to the nearest $0.05 \mathrm{~m}$. Woody species that were present in the area but did not intersect the transect, were likewise noted and included in the floristic analysis with the smallest recordable cover value of $0.05 \mathrm{~m}$. We recorded the number of endemic species in each community sample. The nomenclature of plant species and the classification of species as endemics of west Iberia and north Morocco (i.e. the approximate Drosophyllum range) follows the regional standard Floras (Franco et al., 1984, Valdés et al., 1987; Castroviejo et al., 1986-2000). The woody vegetation structure was characterized using the transect intersection data: Firstly, we computed the mean size of bare soil patches (i.e. vegetation gaps); secondly, we calculated the cover of Drosophyllum plants growing in vegetation gaps and those growing beneath shrubs (see quantitative methods below).

\section{Statistical analyses}

Plant communities were classified by two-way indicator species analyses using the TWINSPAN module of the program PC-ORD (McCune \& Mefford, 1999). Analyses considered both the presence and the cover of recorded plant species. Differences of Drosophyllum population features and environmental parameters among the TWINSPAN-defined groups were analysed by one-way ANOVA or Kruskal-Wallis nonparametric ANOVA.

The relationship between environmental factors and Drosophyllum population characters was assessed by means of forward stepwise multiple regression analyses. All variables were assessed for normality prior to statistical analyses and transformed when necessary. Regressions were carried out with the following dependent variables: population area, plant density, fractions of the three age classes (E-1, E-2 and E-3), and seedling number. The independent variables included in the regression models were: longitude, latitude, altitude, slope, exposure, shrub cover, tree cover, mean size of bare soil patches, as well as the edaphic variables: $\mathrm{pH}$, contents of $\mathrm{CaCO}_{3}$, organic $\mathrm{C}$, total $\mathrm{N}$ and $\mathrm{P}$, and the fractions of coarse sand, fine sand, silt, and clay. Multiple regressions were carried out separately for nonedaphic and edaphic variables, because splitting variables into biologically meaningful subsets helps to improve the interpretability of the relative importance of variables (James \& McCulloch, 1990; Escudero et al., 1999). Prior to the multiple regressions, we carried out a redundancy analysis on independent variables to eliminate those that did not contribute to improvement of the models due to colinearity. All variables showed a tolerance of $>0.2$; that is, each variable contained at least $20 \%$ variation unexplained by the rest of the variables, which suggests a low redundancy (Philippi, 1993).

The habitat preference and dependence on vegetation gaps were examined by paired $t$-test and multiple linear regression. Using the line transect data, we calculated both the observed fraction of plants growing in vegetation gaps and the expected fraction (according to the proportion of vegetation and bare soil gaps along the transect) under the assumption that there was no interaction with shrubs, that is, without spatial aggregation or segregation of shrubs. Subsequently, we examined the geographical variability of Drosophyllum microsite preferences by multiple regression with longitude, latitude, exposure and shrub cover as independent variables, and the relation between observed and expected plant fractions in gaps as dependent variable. All regressions and univariate statistics were performed using STATISTICA (StatSoft, 1997).

\section{RESULTS}

\section{Population character}

Drosophyllum populations varied greatly in their size, density and age structure throughout its geographical range (Tables 1 and 2). Occupied areas ranged between 50 and $\geq 15000 \mathrm{~m}^{2}$, while plant densities varied between 10 and 826 individuals per $200 \mathrm{~m}^{2}$. In general, a proportion of $43 \%, 25 \%$ and $32 \%$ of censused plants were assigned to the age classes E-1, E-2 and E-3, respectively. However, the age structure varied considerably among populations, e.g. E-1 plants were missing in four Portuguese sites, while six Moroccan and southern Spanish populations contained few $(<2 \%)$ individuals of class E-3. The proportion between subadult (E-1) and adult (E-2 and E-3) individuals was not correlated with the occupied population area (Pearson $r=0.16$, 
Table 2 Variation of Drosophyllum population features and environmental parameters among sampled sites comprising the four TWINSPAN groups (mean $\pm 1 \mathrm{sd}$; statistical differences between groups assessed by oneway ANOVA or Kruskal-Wallis nonparametric ANOVA; ns = not significant)

\begin{tabular}{|c|c|c|c|c|c|c|}
\hline$n$ & $\begin{array}{l}\text { all groups } \\
32\end{array}$ & $\begin{array}{l}\text { I } \\
8\end{array}$ & $\begin{array}{l}\text { II } \\
15\end{array}$ & $\begin{array}{l}\text { III } \\
5\end{array}$ & $\begin{array}{l}\text { IV } \\
4\end{array}$ & $P$ \\
\hline Population area $\left(\mathrm{m}^{2}\right)$ & $4153 \pm 5553$ & $2359 \pm 3497$ & $6491 \pm 6730$ & $2768 \pm 4169$ & $704 \pm 793$ & ns \\
\hline Density (ind. $/ 200 \mathrm{~m}^{2}$ ) & $216.3 \pm 232.4$ & $190.9 \pm 204.1$ & $228.9 \pm 226$ & $23.0 \pm 9.3$ & $461.3 \pm 278.4$ & 0.005 \\
\hline E-1 (\%) & $43.2 \pm 28.6$ & $56.6 \pm 20.3$ & $52.5 \pm 27.8$ & $8.3 \pm 13.3$ & $24.7 \pm 15.6$ & 0.001 \\
\hline E-2 $(\%)$ & $25.4 \pm 18.0$ & $24.0 \pm 19.1$ & $30.2 \pm 20.5$ & $16.6 \pm 9.4$ & $20.7 \pm 12.4$ & ns \\
\hline E-3 $(\%)$ & $31.5 \pm 27.4$ & $19.4 \pm 15.9$ & $17.3 \pm 16.6$ & $75.1 \pm 19.3$ & $54.6 \pm 10.8$ & $<0.001$ \\
\hline Seedlings (ind. $/ 200 \mathrm{~m}^{2}$ ) & $11.9 \pm 20.67$ & $30.5 \pm 29.2$ & $9.1 \pm 14.9$ & $0.0 \pm 0.0$ & $0.0 \pm 0.0$ & 0.01 \\
\hline Altitude (m a.s.1.) & $399 \pm 292$ & $125 \pm 64$ & $519 \pm 221$ & $196 \pm 64$ & $751 \pm 363$ & $<0.001$ \\
\hline Slope $\left(^{\circ}\right)$ & $22.7 \pm 15.3$ & $23.1 \pm 17.1$ & $26.3 \pm 17.1$ & $21.0 \pm 5.5$ & $10.0 \pm 7.1$ & ns \\
\hline Exposure $\left({ }^{\circ}\right)^{*}$ & $70 \pm 55.9$ & $52.5 \pm 61.5$ & $70.7 \pm 44.0$ & $78.8 \pm 76.8$ & $90.0 \pm 90.0$ & ns \\
\hline Tree cover $(\%)$ & $14.8 \pm 26.4$ & $8.8 \pm 13.2$ & $10.0 \pm 25.6$ & $28.4 \pm 37.2$ & $26.8 \pm 33.2$ & ns \\
\hline Shrub cover $(\%)$ & $49.9 \pm 19.8$ & $35.6 \pm 24.3$ & $53.6 \pm 14.2$ & $66.0 \pm 20.7$ & $44.4 \pm 8.9$ & 0.03 \\
\hline Vegetation gap size (m) & $0.5 \pm 0.6$ & $0.8 \pm 1.1$ & $0.4 \pm 0.1$ & $0.5 \pm 0.2$ & $0.7 \pm 0.3$ & ns \\
\hline Number ssp. & $10.4 \pm 3.8$ & $8.3 \pm 4.0$ & $12.3 \pm 3.5$ & $10.8 \pm 2.6$ & $7.5 \pm 1.7$ & 0.03 \\
\hline Number endemic spp. & $5.0 \pm 2.7$ & $2.6 \pm 1.3$ & $6.7 \pm 2.9$ & $4.2 \pm 1.1$ & $4.0 \pm 0.8$ & 0.01 \\
\hline $\mathrm{pH}$ & $5.5 \pm 0.7$ & $6.2 \pm 0.5$ & $5.4 \pm 0.5$ & $4.5 \pm 0.4$ & $5.3 \pm 0.8$ & $<0.001$ \\
\hline $\mathrm{CaCO}_{3}$ & $0.3 \pm 0.3$ & $0.6 \pm 0.3$ & $0.4 \pm 0.3$ & $0.0 \pm 0.0$ & $0.0 \pm 0.0$ & $<0.001$ \\
\hline $\mathrm{N}_{\text {total }}(\%)$ & $0.3 \pm 0.3$ & $0.2 \pm 0.2$ & $0.4 \pm 0.3$ & $0.3 \pm 0.2$ & $0.4 \pm 0.3$ & ns \\
\hline Organic C $(\%)$ & $3.7 \pm 3.2$ & $2.1 \pm 2.5$ & $4.1 \pm 3.6$ & $3.9 \pm 2.1$ & $5.2 \pm 3.5$ & ns \\
\hline $\mathrm{P}(\%)$ & $1.8 \pm 1.6$ & $0.7 \pm 1.0$ & $2.0 \pm 1.9$ & $1.8 \pm 1.2$ & $2.8 \pm 1.3$ & ns \\
\hline Coarse sand $(\%)$ & $61.5 \pm 16.7$ & $67.4 \pm 11.2$ & $60.5 \pm 19.0$ & $62.6 \pm 10.0$ & $52.3 \pm 23.9$ & ns \\
\hline Fine sand $(\%)$ & $9.9 \pm 6.5$ & $8.1 \pm 4.1$ & $8.2 \pm 5.3$ & $10.4 \pm 3.2$ & $19.5 \pm 10.1$ & 0.02 \\
\hline Silt $(\%)$ & $15.3 \pm 8.5$ & $11.9 \pm 7.3$ & $13.6 \pm 7.5$ & $21.1 \pm 6.4$ & $20.9 \pm 12.7$ & ns \\
\hline Clay $(\%)$ & $12.7 \pm 11.2$ & $12.6 \pm 10.7$ & $16.4 \pm 13.4$ & $5.9 \pm 2.0$ & $7.4 \pm 2.2$ & ns \\
\hline
\end{tabular}

* measured as deviation from the south.

$n=32, P=0.37$ ), but it did correlate with population density ( $r=0.48, n=32, P=0.006)$.

\section{Plant communities}

Sixteen Drosophyllum populations (53\%) grew in low ( $\leq 1.5 \mathrm{~m}$ tall), sparse scrub dominated by heaths and gorses, while $11(34 \%)$ were found in openings within pine or eucalypt plantations that had obviously replaced former scrublands. One population (site 30) was located in an open cork oak (Quercus suber) stand, and two (sites 1 and 13) were in strongly disturbed sites with almost no shrub cover (Table 1 ).

Throughout the 32 studied sites we recorded a total of 53 woody plant species, of which 18 taxa $(34 \%)$ were endemic of the area under study (Appendix 1). The TWINSPAN analysis revealed four different groups of plant communities (Table 1 and Appendix 1). These groups assembled populations of different geographical regions, although the pattern was partly diffused by effects of man-made physical disturbances. The four floristic groups differed significantly in several environmental characteristics and population features (Table 2 and Fig. 3); following is a brief description of them.

Group I ( 8 sites) included all Moroccan populations as well as two highly disturbed sites from Andalusia (South Spain) and one from Portugal. Stands were generally situated at low elevations, close to the coast, on soils with the highest $\mathrm{pH}$. Their shrub cover was sparsest and contained a low floristic diversity and low degree of endemism. Vegetation of this group was characterized by high abundance of the heaths Erica scoparia and Calluna vulgaris, and presence of Calicotome villosa and Cistus libanotis. On the other hand, Erica umbellata was scarce, and Quercus lusitanica and Tuberaria lignosa were absent (in contrast 

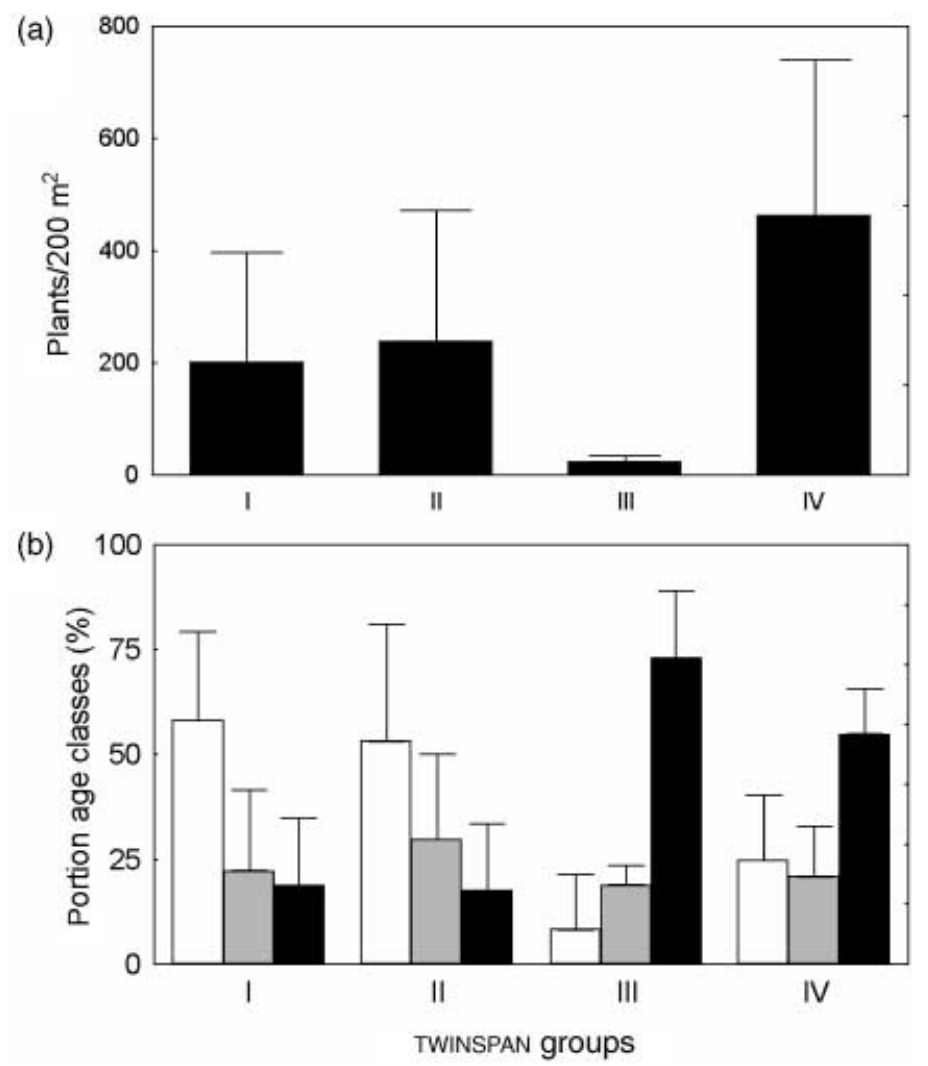

Fig. 3 Variation of Drosophyllum population features among sampled sites of the four TWINSPAN groups: (a) population density $(P=0.006)$; (b) percentage of age class E-1 (white; $P=0.001$ ); E-2 (grey; ns) and E-3 (black; $P<0.001)$. Means and standard deviations are shown.

with their abundance in group II). Drosophyllum populations of these sites were mostly of intermediate size and density, contained the highest proportion of young individuals and the highest seedling density.

Group II (15 sites) assembled most oligotrophic heathlands in the Sierra de Aljibe (north of the Strait of Gibraltar area, on the Spanish side) and the southernmost Portuguese population. Most soil parameters showed intermediate values. These heathlands contained by far the highest floristic richness and degree of endemism. Characteristic species were Calluna vulgaris, Erica umbellata, Genista tridens, G. tridentata, Halimium halimifolium, H. alyssoides, Quercus lusitanica, Satureja salzmannii, Stauracanthus boivini, Thymelaea villosa and Tuberaria lignosa. Populations of Drosophyllum in this group extended over the largest areas, while densities of seedlings and larger plants were intermediate. The proportion of young individuals was comparatively high.

Group III (5 sites) enclosed most sites from the Atlantic coast of Portugal. This vegetation grew on acid soils and formed mostly the understorey of eucalypt and pine plantations at low elevations. The shrub cover was relatively dense and the floristic composition was intermediate between those of group II and IV. Abundant species were Calluna vulgaris, Genista tridentata, Erica umbellata and E. cinerea. The Drosophyllum populations showed by far the lowest density and the highest proportion of old individuals while young plants were scarce and seedlings were not found at all.

Group IV (4 sites) comprised high-elevation inland sites, three of them in western and one in 
Table 3 Multiple regression models for population area, density, percentages of the age classes E-1, E-2 and E-3, and seedling number within 200- $\mathrm{m}^{2}$ sample areas. Analyses include all 32 populations except for seedlings, for which no data were available for populations 21-31. Significant predictors are shown $(* * *: P<0.001$; **: $P<0.01 ; *: P<0.05$ ) with the standardized regression coefficients (in parentheses)

\begin{tabular}{|c|c|c|c|c|c|}
\hline Dependent variable & Predictors & adj. $r^{2}$ & $F$ & $P$ & Significant predictors \\
\hline \multirow[t]{2}{*}{ Area } & No edaphics & & & ns & \\
\hline & Edaphics & & & ns & \\
\hline \multirow[t]{2}{*}{ Density } & No edaphics & 0.33 & 4.90 & 0.004 & longitude** $(-0.80)$ \\
\hline & Edaphics & & & ns & \\
\hline \multirow[t]{2}{*}{ E-3 } & No edaphics & 0.61 & 16.91 & $<0.001$ & latitude*** $(0.71)$ \\
\hline & Edaphics & 0.40 & 11.20 & $<0.001$ & $\mathrm{pH}^{* *}(0.45) ;$ fine sand* $(-0.36)$ \\
\hline \multirow[t]{2}{*}{ E-2 } & No edaphics & & & ns & \\
\hline & Edaphics & & & ns & \\
\hline \multirow[t]{2}{*}{ E-1 } & No edaphics & 0.63 & 9.92 & $<0.001$ & $\begin{array}{l}\text { latitude* }(-0.49) ; \text { shrub cover* }(-0.32) \text {; } \\
\text { exposure* }(-0.24)\end{array}$ \\
\hline & Edaphics & 0.27 & 4.84 & 0.008 & fine sand* $(0.33)$ \\
\hline \multirow[t]{2}{*}{ Seedlings } & No edaphics & 0.72 & 11.25 & $<0.001$ & $\begin{array}{l}\text { exposure*** }(-0.58) \text {; gap size* }(0.40) \\
\text { altitude }^{* *}(-0.42)\end{array}$ \\
\hline & Edaphics & & & ns & \\
\hline
\end{tabular}

central Spain, which included different tree plantations and one heathland. This group showed the lowest floristic diversity, while the proportion of endemic species was comparatively high. Characteristic species of this rather continental scrubs were Erica umbellata, Genista triacanthos and Halimium ocymoides. The Drosophyllum populations of this group were the densest, and the proportion of old individuals was high, while no seedlings were found in the year of sampling.

\section{Relationships between environmental factors and population features}

Four out of six multiple regression models between nonedaphic variables and Drosophyllum population features were significant and showed a moderate to high predictive power (adjusted $r^{2}$ between 0.33 and 0.72 , Table 3 ). The population density decreased westwards, while the age structure showed a significant northward increment of old vs. young individuals. Among vegetation characters, more seedlings were counted in sites where larger vegetation gaps were available, and the fraction of young individuals (class E-1) decreased with increasing shrub cover. Both seedlings and young plants were more abundant in sites with southward exposure. This is a singleyear survey, and given the interannual variability of mediterranean climate, the observed seedling patterns should be considered as preliminary. Among the edaphic variables, only the $\mathrm{pH}$ and the fine sand fraction were related to the percentages of age classes E-1 and E-3, respectively. All other regression models with edaphic variables were not significant.

Drosophyllum plants grew more frequently in patches of bare soil than beneath shrub vegetation (paired $t$-test on expected vs. observed fractions of plants growing on bare soil was significant: $t=3.89$, d.f. $=28, \quad P<0.001)$. This preference increased with denser shrub cover (Fig. 4), while neither the exposure nor the geographical situation of the population showed a significant relationship (multiple linear regression: adj. $r^{2}=0.28, F=3.72$, $P=0.02 ;$ beta $_{\text {shrub cover }}=0.55, P=0.002$ ).

\section{DISCUSSION}

\section{Drosophyllum populations and habitat features across the range}

Our survey revealed that all examined Drosophyllum population parameters vary strongly both within and among different regions of the geographical range. However, despite this large heterogeneity we found a general trend that populations become older and sparser towards 


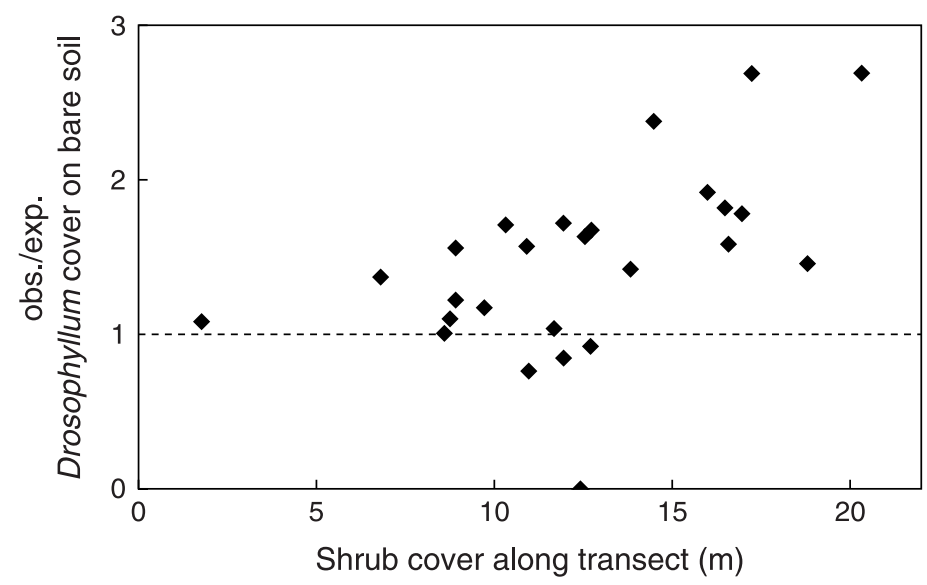

Fig. 4 Ratio of observed and expected Drosophyllum plant fractions growing in vegetation gaps as function of scrub density, for the 32 surveyed populations. See Methods section for details on the procedure.

the north-western edge of the species' range. The latitude of the growing site explained indeed a relatively large part of the variance in age structure, while the multiple regression model on population density yielded a rather low predictive power. Likewise, we found a consistent geographical patterning of the plant communities associated with Drosophyllum and their vegetation structure. Most of the examined abiotic variables experienced likewise more or less large variation among sites, but only a few of them varied significantly among the different plant communities that contained Drosophyllum populations.

Throughout the geographical range of Drosophyllum, we could distinguish two major groups of habitats: (1) largely undisturbed dwarf-shrub scrublands and (2) sites physically disturbed and opened by human activities. The first habitat type comprises heathlands formed by low-stature chamaephytes growing on poor, acid lithosols, which are most common on the northern side of the Strait of Gibraltar (TWINSPAN group II). However, a few isolated sites occur also in central Spain and northern coastal Portugal. The recorded plant communities of this group contain by far the highest floristic diversity and proportion of endemic taxa, which have been attributed to their edaphic particularity (Ojeda et al., 1995, 1996, 2000). Drosophyllum is most common in these areas and phytosociologists have even considered it as a characteristic species of that vegetation type (Müller \& Deil, 2001).
Therefore, Drosophyllum may represent a 'flag' species, which exemplifies best the process of edaphic speciation in the region. It shows an ensemble of features typically associated with endemicity there, e.g. woody habit (uncommon in its taxonomic group) adapted to acidic, poor soils (see Ojeda et al., 2001). Another singularity of Drosophyllum, compared to other endemics there, is the taxonomic level of endemicity. Almost all endemic lineages in the region are species (or subspecies) within widely (Mediterranean) spread genera, such as Bupleurum, Cistus, Cytisus, Erica, Genista, Halimium, Lithodora, Quercus and Satureja. In contrast, Drosophyllum seems to represent a quite isolated and old lineage, which may be considered a separate family of Droseraceae (Williams et al., 1994; Meimberg et al., 2000).

The second group of habitats includes vegetation gaps in pine or eucalypt plantations, as well as quarries, roadsides and firecuts. Large-scale disturbed or heavily cattle-browsed, relatively open areas are assembled in TWINSPAN group I, which forms a floristically impoverished variant of the heathlands comprised in group II (see also Ojeda et al., 1996). Most of these sites are located in north Morocco, where the browsing pressure by cattle is traditionally severe (Ojeda et al., 1995; Moore et al., 1998). The TWINSPAN groups III and IV include mostly tree plantations, which are the most common growing sites of Drosophyllum in Portugal and western Spain. 
They are floristically poorer, dominated by widespread species, and contain less endemics than southern Spanish heathlands.

Floristic differentiation between TWINSPAN groups probably reflects more the degree of human disturbance of original vegetation than the biogeographical differences between areas. The study area (within the Ibero-Mauritanian region) has been recognized as having high floristic richness, with high proportion of singular taxa and endemicity (Takhtajan, 1986; Ojeda et al., 2000). The studied vegetation patches bearing Drosophyllum (with $34 \%$ of narrow endemism among woody species) confirms this picture, at community level. The detrimental effects of global change, mainly changes in land use, on Drosophyllum populations have been documented in Portugal, where it is locally extinct in many old localities (known from old references and herbarium specimens), due to urbanization and human population growth (Correia \& Freitas, 2002). In comparison, most of the populations of Spain and Morocco suffer important but not so definitive disturbances (comparatively, land use has not changed dramatically in those mountain areas). In general, there is a negative association between community richness of endemism and species with the degree of humaninduced disturbance.

\section{Relationships between environmental factors and population performance}

Most carnivorous plants are highly susceptible to competition for light and depend on open interspaces for regeneration (Givnish et al., 1984; Juniper, 1989). This appears also to be the case in Drosophyllum, since recorded abundance of seedlings and young individuals were largely explained by variables related to the light environment (exposure and vegetation gap size), and established Drosophyllum plants were preferentially found in vegetation gaps. This lightdemanding behaviour must be associated, in Mediterranean-type climate, to the ability to tolerate the high irradiation and strong drought stress suffered by plants on open, exposed sites during the summer months. Germination occurs mostly between December and February (B. Garrido, unpublished), and newly emergent seedlings must grow and develop sufficiently large root systems to survive the summer drought; however, many fail and the seedling mortality is high (B. Garrido, unpublished).

Drosophyllum is restricted to acidic soils and probably is benefited by its ability to uptake $\mathrm{N}$ of animal origin, to live in those nutrient-low soils. However, in the regression analyses, the edaphic variables did apparently play a minor role for population performance: The only significant predictors, $\mathrm{pH}$ and fine sand content, were both significantly correlated with latitude $(P<0.01$, respectively), whose predictive power was considerably larger than that of the edaphic variables. If there is an effect of these edaphic variables, beyond the correlation with latitude, remains unknown and should be tested experimentally.

\section{Regeneration and population dynamics in different habitats and regions}

Our survey suggests that heathlands on acidic, oligotrophic soils are the most original and stable habitats for Drosophyllum, as well as for numerous other threatened, endemic taxa in the study area (Appendix 1; Ojeda et al., 1995). Mediterranean heathland species are mostly characterized by slow growth, high persistence and stress tolerance (Ojeda et al., 1995). Apart from occasional fires, natural disturbances are rare in this type of habitat, and we suggest that the recorded demographic structure represents the typical age structure of stable Drosophyllum populations.

In undisturbed heathlands, the species' regeneration is governed by the small-scale vegetation structure and the continuous creation of bare soil patches, which creates a mosaic of suitable sites for recruitment. Drosophyllum recruits preferably where and when gaps are opened, and allow seedlings to establish; that is, it follows a seed bank dominated regeneration strategy (Grubb, 1977). There is some evidence for seed longevity and persistent soil seed bank in this species: buried seeds have remained viable and germinated after three years (B. Garrido \& T. Marañón, unpublished); herbarium stored seeds germinated after 10 years (Correia \& Freitas, 2002); in a Portuguese population, the soil seed bank was estimated in 340 seeds $\mathrm{m}^{-2}$ (Correia \& Freitas, 2002). A seed bank dominated regeneration enhances population persistence at a given site, because it allows to buffer the impact of dry years on the 
regeneration (Kadmon, 1993), so frequent under Mediterranean climate, and to reduce temporal demographic bottlenecks in small populations (Kalisz \& McPeek, 1992), often the case in Drosophyllum. Furthermore, it may help to accelerate the population growth when new areas, within or very close to the population, become available for recruitment. These new open sites may be quickly colonized by larger Drosophyllum groups (cf. Juniper et al., 1989), before they become covered by more competitive woody vegetation. High plant densities (as those found at the sites of TWINSPAN group IV), therefore, do not necessarily indicate stable populations, but may rather be a sign of intense population dynamics after perturbations.

Moroccan Drosophyllum populations experience an active recruitment in the relatively open, intensely grazed scrublands, as indicated by the high numbers of recorded seedlings and subadult plants. On the other hand, many old and large plants in these populations show damage due to browsing, and despite a certain resprouting capacity, Drosophyllum appears to suffer a high mortality from herbivory by goats (B. Garrido, personal observation). The observed 'young' age structure of Moroccan Drosophyllum populations is probably a result of both high recruitment and high mortality; in other words, populations experience an accelerated population turnover, pressured by goat browsing.

Most Portuguese and western-central Spanish Drosophyllum populations, in contrast, show an 'aged' demographic structure, with a dominance of old individuals. Although these populations were mostly censused in July, when the summer drought is already causing seedling mortality, the almost complete absence of seedlings in these sites supports the notion of low recruitment and a marked tendency towards population senescence. Shading by shrubs and the planted trees is probably an important reason for the observed progressive decline in recruitment (see Valverde \& Silvertown, 1998; for a similar effect on a woodland herb). As a secondary effect on longer time scales, the shrub or tree vegetation may progressively increase the nutrient and organic matter content of the soil, and thus also preclude later re-establishments of Drosophyllum populations from the seed bank (see Brewer, 1998; for a comparable case in the carnivorous Drosera capillaris).
The results of the present range-wide survey have revealed regional differences and peculiarities in Drosophyllum population structures and dynamics, which are presumably due to geographical variation in the human exploitation of those growing sites. They could have remained undetected by local or regional-scale studies confined to a single country. These biogeographical patterns reinforce the need of transfrontier studies of threatened plant species, throughout their entire range (see also Gärdenfors, 2001; Rodrigues \& Gaston, 2002).

\section{Inferences about the history of Drosophyllum's range}

Drosophyllum has (to our knowledge) never been found in fossil records, but its phylogenetic singularity and biology (Williams et al., 1994; Meimberg et al., 2000) suggest that this species is an ancient member of the Iberian flora, whose origin dates back to the Tertiary. Despite its restriction to acid, oligotrophic sites and its presumably low ability to colonize distant habitat patches, Drosophyllum occurs in disjunct areas across large parts of the western and central Iberian Peninsula (hereby crossing different floristic regions and established areas of endemism; see García-Barrios et al., 2002).

Some evidence indicates that the range of Drosophyllum has been much more stable through time than the range of most other plant species growing today in Europe (cf. Avise, 2000). Firstly, Drosophyllum is limited to a region well known for its role as Quaternary climate refugium (Hewitt, 2000). Moreover, Drosophyllum populations occur either in mountainous areas, where climate changes would produce relatively small distribution shifts in vertical direction, or close to the coast where sites would be scarcely affected by climatic changes (Hewitt, 2000). The plant communities associated with Drosophyllum populations contain a high number of endemic species with similar range (see Appendix 1), including their presence on both sides of the Strait of Gibraltar (Ojeda et al., 1995, 1996); the last land connection across the Strait dates most probably back to the Messinian (c. 5 My BP; Palmer and Cambefort 2000). These historical prospects should be addressed by a phylogeographical approach, and thus to elucidate the 
location of refugia within the range (putatively the Strait of Gibraltar region) and the routes of colonization/extinction through disjunct ranges.

\section{Current population trends and conservation}

The present survey draws a geographically differentiated picture of the conservation status of Drosophyllum, whose range touches three different countries with considerable differences in their environmental policies: Spain, Morocco and Portugal. (a) Spain. Southern Spain counts with the largest and most stable populations. Ironically, only in this region (Andalusia) Drosophyllum has been included as 'vulnerable' in a Red List of protected plant taxa (BOJA, 1994). However, a more recent work has reconsidered this species at minor risk, because many populations are located in a protected area, Los Alcornocales Natural Park (Blanca et al., 1999). (b) Morocco. Drosophyllum is restricted to a few small edaphic islands, and the species has possibly never been widespread. Populations are few and suffer from intense browsing, although we did not observe remarkable regeneration problems. There is no specific legal protection for Drosophyllum in this country. (c) Portugal. Recent surveys have considered Drosophyllum as a severely threatened species with fragmented distribution, and the large disturbances by construction of housing and infrastructure being main agent causing those population losses (Caldas et al., 1996; Correia \& Freitas, 2002). Our own data indicate that many Portuguese Drosophyllum populations will probably further decline or disappear due to regeneration failure. Many remaining stands of this species are already relictual fragments, and their most common current habitats, pine and eucalypt plantations, will rarely revert to natural scrublands. This geographical pattern, intercountries, should be further explored by detailed analysis of the population loss, through the time, and in all the species range, given that enough historical records are available.

Drosophyllum is biologically well suited to local population persistence; it has high degree of selfing before flower anthesis (Ortega et al., 1995, 1998), and seeds lacking special dispersal mechanisms but persistent in the soil, forming a seed bank. However, it has low ability to colonize distant habitat patches or maintain a regular genetic interchange between its disjunct growing sites. These form a regional population ensemble (sensu Freckelton \& Watkinson, 2002) that does not buffer local extinctions by regional metapopulation dynamics. Conservation efforts should therefore concentrate on conserving the largest possible number of existing local growing sites (according to the recommendations by Freckelton \& Watkinson, 2002).

More specifically, Rodríguez (2002) has proposed a classification of declining types of ranges, with strong implications for the efficient use of conservation resources. Although an exhaustive historical record should be needed to ascertain the declining type, it can be hypothesized that Drosophyllum belongs to the low-abundance-biased (LAB) decline type. It's southern Iberian populations are abundant, dense and show an apparently balanced demographic structure. On the other hand, central and western Iberian populations are sparser, with less regeneration and higher habitat changes; as a consequence, a small further loss of individuals would induce local extinction and range declining in a large part of the species range. Therefore, the most efficient strategy should concentrate on conservation efforts in the higher density areas, e.g. Los Alcornocales Natural Park in southern Spain. In a wider context, the coexistence of highly abundant Drosophyllum with most other narrow endemics in the same area would increase the efficiency of that conservation strategy. However, abundance is only a part of the conservation target.

In addition, it would be desirable to design a transnational program to assess the genetic variability of Drosophyllum throughout its geographical range. Based on this information, to implement conservation and restoration policies, using well-preserved populations as genetic 'sources', to re-establish populations in areas formerly lost for this singular species (besides genus and presumably family) of the Mediterranean flora.

\section{ACKNOWLEDGMENTS}

We are most indebted to Redouan Ajbilou, F. Barreto Caldas, M. Joao Gonçalves, Antonio Jordán, Joao Ormonde, Ana Ortega, Iñigo Sánchez, and the colleagues in the Núcleo de Ecologia Vegetal of the Universidade do Porto, the Universidade de Coimbra, and the Jardin 
Botánico de Lisboa for providing us with preliminary information to locate populations and helping with field sampling. M. Eugenia Díaz, M. Dolores Díez, Ernesto Gallego, Pedro Garrido, Rosario Hidalgo and Anass Terrab also helped with field sampling. Rafael López and the staff of the Soil Laboratory at the IRNA carried out the soil analyses. Rodrigo Tavera for drawing the Fig. 2. J.P. Rodríguez and one anonymous reviewer for their comments improving an earlier version of the manuscript. Fieldwork was supported by DGICYT grant PB95-551, T.M. was supported by DGES grant PB97-1177, and A.H and J.A. by DGESIC grant PB 98-1144.

\section{REFERENCES}

Allen, S.E. (1989) Chemical Analysis of Ecological Materials. Blackwell, Oxford.

Avise, J.C. (2000) PhyloGeography: The History and Formation of Species. Harvard University Press, Cambridge, USA.

Blanca, G., Cabezudo, B., Hernández-Bermejo, J.E., Herrera, C.M., Molero Mesa, J., Muñoz, J. \& Valdés, B. (1999) Libro Rojo de la Flora Silvestre Amenazada de Andalucía. Consejería de Medio Ambiente, Junta de Andalucía.

BOJA no. 107 (1994) Decreto 104/1994, de 10 de Mayo, por el que se establece el Catálogo Andaluz de la Flora Silvestre Amenazada. Junta de Andalucía, Sevilla.

Brewer, J.S. (1998) Effects of competition and litter on a carnivorous plant, Drosera capillaris (Droseraceae). American Journal of Botany 85, 1592-1596.

Brown, J.H., Stevens, G.C. \& Kaufman, D.M. (1996) The geographic range: Size, shape, boundaries, and internal structure. Annual Review of Ecology and Systematics 27, 597-623.

Caldas, F.B., Séneca, A.M., Almeida da Silva, R., Carvalho, A.C.H., Aguiar Branco, H., Alves, H.N., Honrado, J.J. (1996) Distribuição Geográfica e Estatuto de Ameaça das Espécies da Flora a Proteger. Relatório do Projecto Conhecimento e Gestão do Património Natural de Portugal. Contrato Life, B., 4-3200/93/771. ICETA. Universidade do Porto.

Castroviejo et al., eds (1986-2000) Flora Ibérica: Plantas vasculares de la Península Ibérica e Islas Baleares, Volumes. I-VIII. Real Jardín Botánico, CSIC. Madrid.

Correia, E. \& Freitas, H. (2002) Drosophyllum lusitanicum, an endangered West Mediterranean endemic carnivorous plant: threats and its ability to control available resources. Botanical Journal of the Linnean Society 140, 383-390.
Darwin, C. (1875) Insectivorous Plants. John Murray, London.

Escudero, A., Somolinos, R.C., Olano, J.M. \& Rubio, A. (1999) Factors controlling establishment of Helianthemum squamatum, an endemic gypsophile of semi-arid Spain. Journal of Ecology 87, 290-302.

Fennane, M. \& Ibn Tattou, M. (1998) Catalogue des plantes vasculaires rares, menacées ou endémiques du Maroc. Bocconea 8, 1-243.

Franco, J.M.A.P. (1984) Nova Flora de Portugal (Continente e Açores), Clethraceae-Compositae Vol. II Astória, Lisboa.

Freckleton, R.P. \& Watkinson, A.R. (2002) Largescale spatial dynamics of plants: metapopulations, regional ensembles and patchy populations. Journal of Ecology 90, 419-434.

García-Barrios, E., Gurrea, P., Luciáñez, J.M., Cano, J.M., Munguira, J.M., Moreno, J.C., Sainz, H., Sanz, M.J. \& Simón, J.C. (2002) Parsimony analysis of endemicity and its application to animal and plant geographical distributions in the Ibero-Balearic region (western Mediterranean). Journal of Biogeography 29, 109-124.

Gärdenfors, U. (2001) Classifying threatened species at national versus global levels. Trends in Ecology and Evolution 16, 511-516.

Givnish, T.J., Burkhardt, E.L., Happel, R.E. \& Weintraub, J.D. (1984) Carnivory in the bromeliad Brocchinia reducta, with a cost/benefit model for the general restriction of carnivorous plants to sunny, moist, nutrient-poor habitats. American Naturalist 124, 479-497.

Grubb, P.J. (1977) The maintenance of species-richness in plant communities: the importance of the regeneration niche. Biological Review of the Cambridge Philosophical Society 52, 107-145.

Hewitt, G.M. (2000) The genetic legacy of the ice ages. Nature 405, 907-913.

Heywood, V.H. (1993) Flowering Plants of the World, 2nd edn. Oxford University Press, Oxford, UK.

James, F.C. \& McCulloch, C.E. (1990) Multivariate analysis in ecology and systematics: Panacea or Pandora's box? Annual Review of Ecology and Systematics 21, 129-166.

Joshi, J., Schmid, B., Caldeira, M.C., Dimitrakopoulos, P.G., Good, J., Harris, R., Hector, A., Huss-Danell, K., Jumpponen, A., Minns, A., Mulder, C.P.H., Pereira, J.S., Prinz, A., Scherer-Lorenzen, M., Terry, A.C., Troumbis, A.Y. \& Lawton, J.H. (2001) Local adaptation enhances performance of common plant species. Ecology Letters 4, 536-544.

Juniper, B.E., Robins, R.J. \& Joel, D.M. (1989) The Carnivorous Plants. Academic Press, London.

Kadmon, R. (1993) Population dynamic consequences of habitat heterogeneity: An experimental study. Ecology 74, 816-825.

Kalisz, S. \& McPeek, M. (1992) Demography of an age-structured annual: Resampled projection 
matrices, elasticity analyses, and seed bank effects. Ecology 73, 1082-1093.

Lobo, J.M., Castro, I. \& Moreno, J.C. (2001) Spatial and environmental determinants of vascular plants species richness distribution in the Iberian Peninsula and balearic Islands. Biological Journal of the Linnean Society 73, 233-253.

McCune, B. \& Mefford, M.J. (1999) PC-ORD. Multivariate Analyses of Ecological Data, Version 4. MjM Software Design, Gleneden Beach, Oregon.

Meimberg, H., Dittrich, P., Bringmann, G., Schlauer, J. \& Heubl, G. (2000) Molecular phylogeny of Caryophyllidae s.l. based on matK sequences with special emphasis on carnivorous taxa. Plant Biology 2, 218-228.

Moore, H.M., Fox, H.R., Harrami, M.C. \& El Alami, A. (1998) Environmental challenges in the Rif mountains, northern Morocco. Environmental Conservation 25, 354-365.

Müller, J. \& Deil, U. (2001) Ecology and structure of Drosophyllum lusitanicum (L.) Link populations in the southwestern part of the Iberian Peninsula. Acta Botanica Malacitana 26, 47-68.

Ojeda, F., Arroyo, J. \& Marañón, T. (1995) Biodiversity components and conservation of Mediterranean heathlands in southern Spain. Biological Conservation 72, 61-72.

Ojeda, F., Marañón, T. \& Arroyo, J. (1996) Patterns of ecological, chorological and taxonomic diversity at both sides of the Strait of Gibraltar. Journal of Vegetation Science 7, 63-72.

Ojeda, F., Marañón, T. \& Arroyo, J. (2000) Plant diversity patterns in the Aljibe Mountains (S Spain): a comprehensive account. Biodiversity and Conservation 9, 1323-1243.

Ojeda, F., Simmons, M.T., Arroyo, J., Marañón, T. \& Cowling, R.M. (2001) Biodiversity in South African Fynbos and Mediterranean heathland. Journal of Vegetation Science 12, 867-874.

Ortega, A., Carrasco, J.P. \& Devesa, J.A. (1995) Floral and reproductive biology of Drosophyllum lusitanicum (L.) Link (Droseraceae). Botanical Journal of the Linnean Society 118, 331-351.

Ortega-Olivencia, A., López Paredes, J.A., Rodriguez-Riaño, T. \& Devesa, J.A. (1998) Modes of self-pollination and absence of cryptic selfin- compability in Drosophyllum lusitanicum (Droseraceae). Botanica Acta 111, 474-480.

Palmer, M. \& Cambefort, Y. (2000) Evidence for reticulate paleogeography: Beetle diversity linked to connection-disjunction cycles of the Gibraltar Strait. Journal of Biogeography 27, 403-416.

Peterken, G.P. \& Game, M. (1984) Historical factors affecting the number and distribution of vascular plants in the woodlands of central Lincolnshire. Journal of Ecology 72, 155-182.

Philippi, T.E. (1993) Multiple regression analysis: Herbivory. In: Design and Analysis of Ecological Experiments (eds S.M. Scheiner \& J. Gurevitch), pp. 183-210. Chapman \& Hall, New York.

Rodrigues, A.S.L. \& Gaston, K.J. (2002) Rarity and conservation planning across geopolitical units. Conservation Biology 16, 674-682.

Rodríguez, J.P. (2002) Range contraction in declining North American bird populations. Ecological Applications 12, 238-248.

Sagarin, R.D. \& Gaines, S.D. (2002) The 'abundant center' distribution: To what extent is it a biogeographical rule? Ecology Letters 5, 137-147.

Scott, J.M., Murray, M., Wright, R.G., Csuti, B., Morgan, P. \& Pressey, R.L. (2001) Representation of natural vegetation in protected areas: Capturing the geographic range. Biodiversity and Conservation 10, 1297-1301.

StatSoft, Inc. (1997) STATISTICA for Windows. Tulsa, Oklahoma, USA.

Takhtajan, A. (1986) Floristic Regions of the World. University of California Press, Berkeley.

Thompson, J.N. (1994) The Coevolutionary Process. Chicago University Press, Chicago.

Valdés, B., Talavera, S. \& Fernández-Galiano, E., eds (1987) Flora Vascular de Andalucía Occidental. Ketres, Barcelona.

Valverde, T. \& Silvertown, J. (1998) Variation in the demography of a woodland understory herb (Primula vulgaris) along the forest regeneration cycle: Projection matrix analysis. Journal of Ecology 86, 545-562.

Williams, S.E., Albert, V.A. \& Chase, M.W. (1994) Relationships of Droseraceae: A cladistic analysis of rbcL sequence and morphological data. American Journal of Botany 81, 1027-1037. 
Appendix I Floristic composition of plant communities bearing Drosophyllum populations. Four site groups were identified based on TWINSPAN analyses. Within groups, the left column shows the mean cover along the 25-m transect (in $\mathrm{m}$ ) and the right column the frequency of occurrence (percentage). *: endemism of the region covered by the present study

\begin{tabular}{|c|c|c|c|c|c|c|c|c|}
\hline & \multicolumn{8}{|c|}{ TWINSPAN GROUPS } \\
\hline & I & & II & & III & & IV & \\
\hline Arbutus unedo L. & 0.05 & 12.5 & 0.17 & 40 & & & & \\
\hline Bupleurum foliosum Salzm. ex DC* & & & 0.05 & 13.3 & & & & \\
\hline Calicotome villosa (Poiret) Link & 0.45 & 25 & & & & & & \\
\hline Calluna vulgaris (L.) Hull & 1.16 & 87.5 & 3.71 & 93.3 & 3.73 & 100 & & \\
\hline Cistus crispus L. & 3.52 & 62.5 & 0.22 & 33.3 & 0.1 & 20 & 2.85 & 25 \\
\hline Cistus ladanifer L. & 3.25 & 12.5 & 1.88 & 20 & & & 5.6 & 50 \\
\hline Cistus libanotis L.* & 0.7 & 12.5 & & & & & & \\
\hline Cistus populifolius L.* & & & 0.55 & 20 & & & & \\
\hline Cistus salvifolius L. & 0.15 & 37.5 & 0.53 & 60 & 0.78 & 40 & 0.25 & 50 \\
\hline Cytisus striatus (Hill) Rothm.* & & & 0.15 & 6.7 & & & & \\
\hline Cytisus tribracteolatus Webb* & & & 0.05 & 6.7 & & & & \\
\hline Daphne gnidium L. & 0.1 & 12.5 & 0.05 & 20 & & & 0.1 & 20 \\
\hline Drosophyllum lusitanicum (L.) Link* & 2.31 & 100 & 0.92 & 100 & 1.34 & 100 & 2.09 & 80 \\
\hline Erica arborea $\mathrm{L}$. & & & & & 0.05 & 20 & & \\
\hline Erica australis L.* & 4.15 & 12.5 & 0.77 & 33.3 & & & 1.3 & 25 \\
\hline Erica ciliaris $\mathrm{L}$. & 0.05 & 12.5 & 0.05 & 6.7 & & & & \\
\hline Erica cinerea $\mathrm{L}$. & & & & & 2.3 & 80 & & \\
\hline Erica scoparia L. & 4.29 & 50 & 1.6 & 13.3 & & & & \\
\hline Erica umbellata L.* & 0.65 & 12.5 & 2.01 & 53.3 & 5.93 & 100 & 3.37 & 75 \\
\hline Eucalyptus globulus Labill. & & & 0.3 & 6.7 & 1.53 & 40 & & \\
\hline Eucalyptus sp. & 0.05 & 12.5 & & & & & & \\
\hline Genista monspessulana (L.) L. Johnson & 0.2 & 12.5 & & & & & & \\
\hline Genista triacanthos Brot.* & 1.55 & 12.5 & 0.53 & 20 & 1.68 & 40 & 0.52 & 75 \\
\hline Genista tridens (Cav.) D.C.* & 0.1 & 12.5 & 1.63 & 66.7 & & & & \\
\hline Genista tridentata $\mathrm{L} . *$ & 0.45 & 12.5 & 0.78 & 53.3 & 1.56 & 100 & 0.58 & 50 \\
\hline Halimium alyssoides (Lam.) C. Koch* & 0.2 & 12.5 & 1.52 & 40 & & & & \\
\hline Halimium halimifolium (L.) Willk. & 1.61 & 50 & 1.3 & 53.3 & & & & \\
\hline Halymium ocymoides (Lam.) Willk.* & & & & & 0.55 & 60 & 2.28 & 75 \\
\hline Lavandula stoechas $\mathrm{L}$. & 0.44 & 75 & 0.35 & 73.3 & 0.28 & 40 & 0.3 & 25 \\
\hline Lithodora prostrata ssp. lusitanica (Samp.) Valdés* & 0.3 & 25 & 0.05 & 13.3 & 0.25 & 20 & & \\
\hline Myrtus communis L. & & & 0.05 & 6.7 & & & & \\
\hline Osyris alba $\mathrm{L}$. & 0.15 & 12.5 & 0.05 & 6.7 & & & 0.4 & 25 \\
\hline Osyris quadripartita Salzm. ex Decne & & & 1.68 & 13.3 & & & & \\
\hline Phillyrea angustifolia $\mathrm{L}$. & 0.42 & 37.5 & 0.08 & 13.3 & 0.75 & 20 & 0.05 & 25 \\
\hline Pinus pinaster Aiton & 0.33 & 25 & 0.65 & 20 & 0.05 & 20 & 1.3 & 25 \\
\hline Pinus radiata D. Don & & & 0.1 & 6.7 & & & & \\
\hline Pinus pinea $\mathrm{L}$. & & & 0.05 & 20 & 0.05 & 40 & & \\
\hline Pistacia lentiscus L. & 0.8 & 12.5 & & & & & & \\
\hline Quercus lusitanica Lam.* & & & 0.84 & 53.3 & 1.83 & 40 & & \\
\hline Quercus suber L. & 1.35 & 25 & 0.17 & 33.3 & 0.65 & 20 & 0.2 & 25 \\
\hline Rosmarinus officinalis L. & & & 1.8 & 6.7 & & & & \\
\hline Rubus ulmifolius Schott & & & & & & & 0.5 & 25 \\
\hline Satureja salzmannii P.W. Ball* & 0.05 & 12.5 & 0.82 & 46.7 & & & & \\
\hline Smilax aspera $\mathrm{L}$. & & & 0.15 & 6.7 & & & & \\
\hline Stauracanthus boivini (Webb) Samp.* & 0.58 & 25 & 4.35 & 93.3 & & & & \\
\hline Stauracanthus genistoides (Brot.) Samp.* & 0.6 & 12.5 & 6.75 & 6.7 & & & & \\
\hline
\end{tabular}


Appendix I continued.

\begin{tabular}{|c|c|c|c|c|c|c|c|c|}
\hline & \multicolumn{8}{|c|}{ TWINSPAN GROUPS } \\
\hline & I & & II & & III & & IV & \\
\hline Teucrium fruticans $\mathrm{L}$. & & & 0.2 & 6.7 & & & & \\
\hline Thymelaea villosa (L.) Endl. & & & 0.06 & 60 & & & & \\
\hline Thymus caespitosus Brot. & & & & & 0.75 & 40 & & \\
\hline Tuberaria lignosa (Sweet) Samp. & & & 0.06 & 60 & 0.23 & 60 & 0.25 & 25 \\
\hline Ulex micranthus Lange & 0.2 & 12.5 & & & 5.07 & 60 & & \\
\hline Ulex sp1 & & & & & 3.5 & 40 & & \\
\hline Ulex $\mathrm{sp} 2$ & & & & & 0.1 & 20 & & \\
\hline
\end{tabular}

